\title{
Estudios sobre el calor de hidratación desarrollado en morteros con materiales puzolánicos: naturales y subproductos industriales
}

\section{Studies about the heat of hydration developed in mortars with natural and by-product materials}

\author{
M. I.SÁNCHEZ de ROJAS, M. FRÍAS y J. RIVERA \\ Instituto de Ciencias de la Construcción Eduardo Torroja (CSIC)
}

Fecha de recepción: 9-XII-99

Fecha de aceptación: 29-III-00

ESPAÑA

\section{RESUMEN}

Con la incorporación de materiales con características puzolánicas en morteros y hormigones se puede rebajar el calor desarrollado en las reacciones de hidratación. Sin embargo, la disminución en el calor de hidratación no es directamente proporcional a la cantidad de cemento sustituido, esto es debido al aporte de calor generado en la reacción puzolánica, de forma que con materiales muy activos, como el humo de sílice o las rocas opalinas, incluso se incrementa.

\section{SUMMARY}

The heat of hydration developed in reactions of mortars and concretes can be sensibly reduced using pozzolanic materials. However, the decrease of the heat of hydration is not directly proportional to the amount of cement substituted, because of the heat released in the pozzolanic reaction. With materials of high pozzolanic activity as silica fume or opaline rocks very, the heat is even increased.

\section{1.- INTRODUCCIÓN}

Las reacciones de hidratación del cemento portland son altamente exotérmicas, provocando el calentamiento de la pasta. El desarrollo de calor es rápido durante el fraguado y parte del endurecimiento, disminuyendo progresivamente al hacerse la hidratación más lenta, hasta llegar a estabilizarse. Así, en los primeros 3 días se genera el $50 \%$ del calor y el $80 \%$ hasta los 7 días (1).

Sin embargo, en las primeras horas se producen variaciones importantes de temperatura que pueden ser causa de retracciones, que a su vez dan como resultado el agrietamiento observado en algunas obras de construcción que emplean grandes masas de hormigón

\section{1.- INTRODUCTION}

The hydration reactions in portland cement are highly exothermal, producing the heating of the paste. The heat development is quick during the setting and part of the hardening process,

decreasing progressively as the hydration is slower, until it is stable. So, in the first 3 days of hydration, the $50 \%$ of the heat is generated and; an $80 \%$ until 7 days of reaction (1).

However, in the first hours, important temperature variations are produced that may cause shrinkage, leading to the cracking observed in some building 
o en estructuras en las que se utilizan mezclas ricas en cemento (2).

En este aporte de calor debido a procesos de hidratación participan los distintos constituyentes del cemento, de forma que es el aluminato tricálcico con $207 \mathrm{cal} / \mathrm{g}$ y la cal libre con $279 \mathrm{cal} / \mathrm{g}$ los que más calor desarrollan, y siendo el silicato bicálcico el que menos, con $62 \mathrm{cal} / \mathrm{g}(1)$.

Por lo tanto, el calentamiento en la hidratación del cemento es función de la proporción de sus distintos constituyentes, de forma que es importante conocer y cuantificar el contenido de los mismos, así como de los materiales que sean incorporados como adiciones.

Por este motivo, cuando a través de la incorporación de puzolanas se quieran elaborar cementos de bajo calor de hidratación, la selección de los materiales a adicionar es un tema a tener en cuenta, como se ha puesto de relieve en trabajos de investigación previos (3-6).

En esta investigación se han elegido materiales con carácter puzolánico, tanto de origen natural como artificial (subproductos industriales o materiales activados térmicamante), así como un filler calizo, para ser adicionado a un cemento portland, que sirve como referencia.

\section{2.-ESTUDIOSEXPERIMENTALES}

\section{MATERIALES}

Los materiales estudiados abarcan: puzolanas de origen natural, subproductos industriales, materiales que necesitan un tratamiento térmico previo a su utilización y un filler calizo. Todos ellos se comparan entre sí cuando forman parte de morteros elaborados con el mismo tipo de cemento base.

\section{- Materiales puzolánicos naturales}

- Puzolana natural: se trata de un material con un alto contenido en silicio, aluminio y hierro, cuya suma (expresada en óxidos) supone más del $70 \%$ de su composición química. El compuesto cristalino principal es la augita, importante constituyente de las rocas eruptivas.

- Toba volcánica: por su origen (toba traquítica), presenta un alto contenido en álcalis $(8,7 \%)$. Los constituyentes principales son feldespatos y ceolitas.

- Tierra de diatomeas: presenta un valor elevado de pérdida por calcinación $(15,8 \%)$, y los constituyentes works using large concrete amounts or in structures in which rich cement mixes are used (2).

In this heat contribution due to hydration processes, the different cement constituents participate. The tricalcium aluminate with $207 \mathrm{cal} / \mathrm{g}$ and free lime with $279 \mathrm{cal} / \mathrm{g}$ are those developing highest heat and the lowest heat contribution is given by bicalcium silicate with $62 \mathrm{cal} / \mathrm{g}$ (1).

Thus, the heating in cement hydration is a function of the proportion of their different constituents. So, it is important to know and quantify their contents, as well as those of the materials incorporated as additions.

When low-hydration cements must be elaborated through the incorporation of pozzolanic materials, the selection of these materials must be considered, as it has been mentioned in previous works (3-6).

In this research, natural and by-product materials ( by-product or thermally activated materials), likewise lime filler has been chosen as cement additions.

\section{2.- EXPERIMENTAL STUDIES}

\section{MATERIALS}

The materials studied are: natural pozzolans, industrial by-products, materials that need a previous thermal treatment and lime filler. All of them are compared among themselves when forming part of mortars elaborated with the same cement.

\section{- Natural pozzolanic materials}

- Natural pozzolan: it is a material with a high content of silicon, aluminium and iron, whose sum (express as oxides) suppose more than $70 \%$ of its chemical composition. The main crystalline compound is the augite, important constituent of eruptive rocks.

- Volcanic tuff: from its origin (trachitic tuff), it presents a high content of alkalis (8.7\%). The main constituents are feldspars and zeolites.

- Diatomaceous earth: it presents a high loss of ignition (15. 8\%) and the main constituents are 
principales son los óxidos de silicio y calcio. Por DRX se observa la presencia de calcita y ópalo-CT.

- Roca opalina: material de origen sedimentario, constituido principalmente de sílice (87, $7 \%$ ), en estado amorfo o de baja cristalinidad (ópalo A prácticamente amorfo y ópalo CT de cristobalita-tridimita).

\section{- Subproductos industriales}

- Ceniza volante: generada en una Central Termoeléctrica que utiliza carbón de hulla como combustible. El valor de pérdida por calcinación $(0,9 \%)$ pone de relieve un bajo contenido de inquemados, detectándose silicio, aluminio, hierro y un bajo contenido en cal (2, 9\%). Los

compuestos cristalinos mayoritarios son cuarzo, mullita y hematite.

- Humo de sílice: este subproducto industrial procedente de la fabricación de silicio y ferrosilicio, tiene un alto contenido en $\mathrm{SiO}_{2}(>90 \%)$, que se encuentra en estado amorfo, lo que le confiere un alto grado de actividad puzolánica.

\section{- Productos activados térmicamante}

- Ceniza de cáscara de arroz: este material se ha obtenido mediante un horno piloto diseñado para este fin (7). La sílice presente, con un contenido del $91,3 \%$, se encuentra, en su mayor parte, como sílice amorfa y, en menor medida, como cristobalita y tridimita.

- Metacaolín: este producto se produce por calcinación de la caolinita. Tiene un contenido en $\mathrm{SiO}_{2}$ del $51,60 \%$ y 41 , $30 \%$ de $\mathrm{Al}_{2} \mathrm{O}_{3}$. Su baja cristalinidad (existen fases cristalinas de cuarzo, mica y moscovita) hace que sea un producto de alta actividad puzolánica .

\section{- Material no puzolánico}

- Filler calizo: el compuesto principal es la calcita. El análisis químico muestra que existen pequeñas cantidades de silicio y aluminio.

\section{- Cemento de referencia}

El cemento utilizado es un Tipo CEM I/42.5 R, según la designación de la Norma Española UNE 80301 (8), que presenta un contenido en clinker igual o superior al $95 \%$, y que puede llevar incorporados otros componentes adicionales hasta el $5 \%$.

\section{- Arena}

En la elaboración de los morteros, la arena empleada es de origen silícico, con un contenido de sílice superior al $98 \%$ y un tamaño de partícula menor a $2 \mathrm{~mm}$. calcium and silicon oxides. By means of XRD, the presence of calcite and opal-CT can be observed.

- Opaline rock: material with sedimentary origin, constituted by silica (87. 7\%) in amorphous or low.crystallinity state (A opal practically amorphous and CT opal of crystobalite-trydimite).

\section{- Industrial by-products}

- Fly ash: generated in a thermoelectric Power Station that uses hulla carbon as combustible. The loss of ignition (0. 9\%) indicates a low content of unburned elements, detecting silicon, aluminium, iron and low content in lime (2. 9\%). Crystalline compounds are quartz, mullite and hematite.

- Silica fume: this industrial by-product from the silicium and ferrosilicium manufacturing has a high (>90\%) silica content in amorphous state, giving it a higher pozzolanic activity degree.

\section{- Thermally activated products}

- Rice husk ash: this material has been obtained in a pilot furnace designed for this aim (7). The silica present, with a 91. 3\% content is as amorphous silica mainly and cristobalite and trydimite in less degree.

- Metakaolin: this product is obtained by calcination of kaolinite. It has a silica content of $51.60 \%$ and 41. $30 \%$ of alumina. Its low crystallinity (there are quartz, mica and muscovite as crystalline phases) makes it a high pozzolanic activity product.

\section{- Non pozzolanic material}

- Lime filler: the main compound is calcite. The chemical analysis shows small quantities of silicium and aluminium.

\section{- Reference cement}

The cement used is a CEM I/42.5 $R$ type according to the Spanish Standard UNE 80301 (8), with clinker content equal or higher than $95 \%$, that can have other additional components up to $5 \%$.

\section{- Sand}

In the mortars elaboration, the sand used is from siliceous origin with silica content higher than $98 \%$ and a particle size lower than $2 \mathrm{~mm}$. 


\section{ENSAYOS}

Primeramente, en todos los materiales se fija unos valores de finura comprendida entre 4.000 y $5.000 \mathrm{~cm}^{2} / \mathrm{g}$ de superficie específica, obtenida por granulometría láser (9), dada la importancia que este parámetro tiene en la reactividad de lo materiales y, por tanto, en el calor de hidratación, especialmente en los primeros momentos del ensayo. En el caso del humo de sílice, la superficie específica aumenta hasta $5.600 \mathrm{~cm}^{2} / \mathrm{g}$, valor muy bajo para este tipo de productos, que suele tener finuras más elevadas.

La preparación de las mezclas (cemento + adición) se realiza en un mezclador de polvo de alta velocidad, que garantiza la perfecta homogeneidad de los materiales tratados sin perturbar su granulometría.

Proporción Cemento referencia/adición (\% en peso): $100 / 0$ y $70 / 30$.

Para el humo de sílice, metacaolín y ceniza volante, se realizan, además, la mezcla: 90/10, para comprobar el efecto del porcentaje de adición incorporado.

Con estas mezclas se preparan morteros, donde la proporción arena/cemento mixto es de $3 / 1$, y la relación agua/cemento es de 0,5 .

- El calor de hidratación se calcula siguiendo el método recogido en la normativa española (10) del Calorímetro de Langavant. Este método semiadiabático (11) consiste en la cuantificación del calor generado en la hidratación de un cemento, utilizando como calorímetro un vaso de Dewar 0 , más exactamente, una botella térmicamente aislante.

Para ello, se confecciona con el cemento objeto de estudio un mortero que se coloca en un bote cerrado, que a su vez se introduce en la botella aislante. La temperatura desarrollado por este mortero durante el curso de la hidratación se compara con la de un mortero térmicamente inerte (amasado con anterioridad, por lo menos desde tres meses antes del ensayo, según la norma mencionada), y contenido en otra botella aislante utilizada como patrón o testigo.

- La actividad puzolánica de los materiales se estudia mediante un método acelerado, siguiendo la reacción entre el material y una solución saturada de cal en el tiempo. El ensayo consiste en poner la muestra en contacto con la solución saturada de cal a $40 \pm 1^{\circ} \mathrm{C}$ durante 2 horas, 1, 7, 28 y 90 días. Al término de cada período de tiempo se valora la concentración de $\mathrm{CaO}$ en la solución. La cal fijada en $\mathrm{mM} / \mathrm{L}$ se obtiene por diferencia entre la concentración en la solución saturada de cal de referencia $(17,68 \mathrm{mM} / \mathrm{L})$ y la solución en contacto con la muestra.

\section{TESTS}

First, in all materials, fineness values between 4.000 and $5.000 \mathrm{~cm}^{2} / \mathrm{g}$ of specific surface are fixed, obtained by laser granulometry (9), due to the great importance of this parameter in the reactivity of materials and, thus, on the heat of hydration, especially in the first moments of test. In the case of silica fume, the specific surface increases up to $5.600 \mathrm{~cm}^{2} / \mathrm{g}$, a low value for this type of products that use to be finer.

The preparation of mixes (cement + admixture) is carried out in a high speed dust mixer, assuring the homogeneity of the materials without the variation of granulometry.

Proportion reference cement /admixture (\% weight): $100 / 0$ and $70 / 30$

For the silica fume, metakolin and fly ash, the mix 90/10 is also realiced out to confirm the effect of the percentage incorporated.

With these mixes, mortars are prepared, where the proportion sand/cement is $3 / 1$ and the water/cement ratio is 0.5 .

- The heat of hydration is calculated following the method collected in the Spanish Standard (10) about the Langavant Calorimeter. This semi adiabatic method (11) consists of the quantification of the heat generated in the hydration of a cement, using as calorimeter a Dewar flask, or, more exactly, an isolated bottle.

The cement studied is placed in a sealed flask at the same time placed in a isolated bottle. The temperature developed by this mortar during the hydration process is compared to that of a mortar chemically inert (previously mixed, at least three months before the test, according to the Standard) and placed in another isolated bottle used as reference.

- The pozzolanic activity of the materials is studied through an accelerated method, following the reaction between the material and the lime-saturated solution with time. The test consists of placing the sample in contact with a lime-saturated solution at $40 \pm 1{ }^{\circ} \mathrm{C}$ during two hours, 1, 7, 28 and 90 days. At the end of each time period, the $\mathrm{CaO}$ concentration in solution is titrated. The lime fixed (in $\mathrm{mM} / \mathrm{L}$ ) is obtained by difference between the concentration in the lime saturated solution, of reference (17. $68 \mathrm{mM} / \mathrm{L})$ and the sample. 


\section{3.- RESULTADOS Y DISCUSIÓN}

En las figuras 1, 2, 3 y 4 se recogen la evolución del calor de hidratación con el tiempo, hasta la edad de 5 días (120 horas), de los morteros preparados con los diferentes materiales utilizados, con una relación cemento/adición: 70/30.

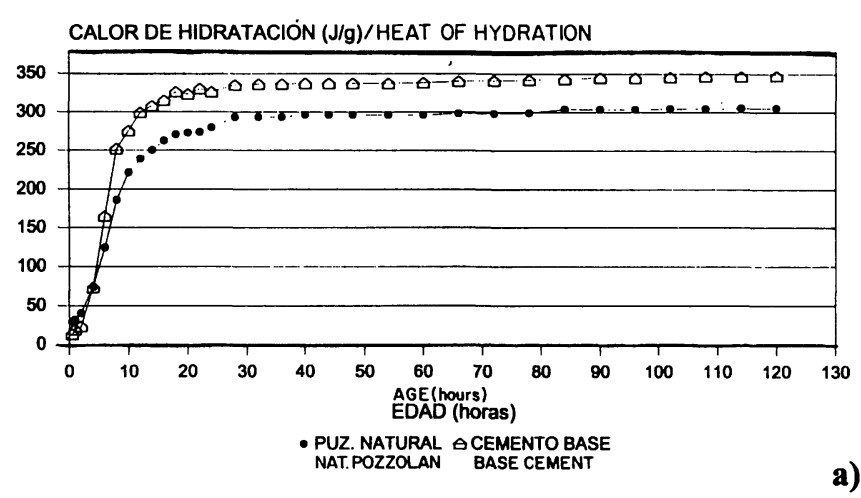

a)

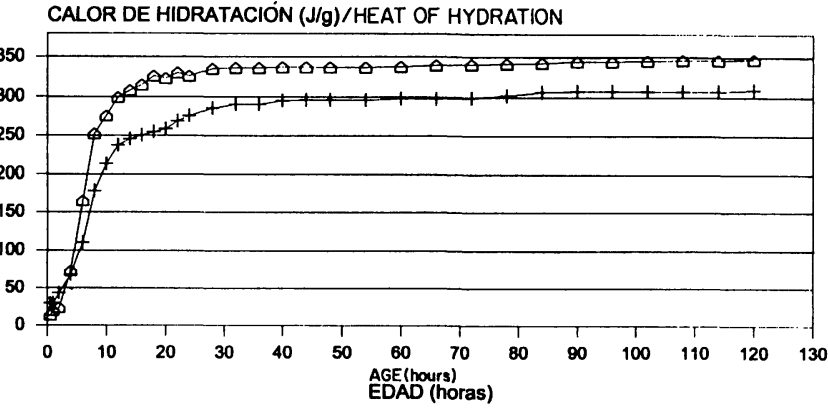

+ TOBA
VOLC.
TUFF

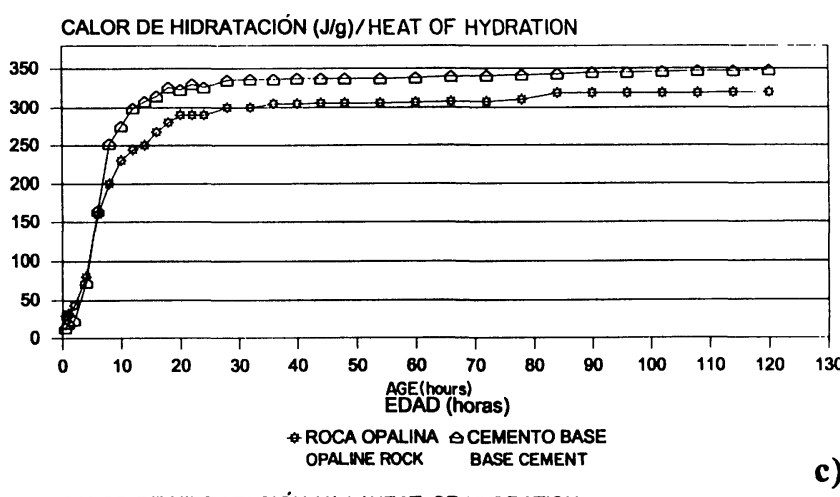

b)
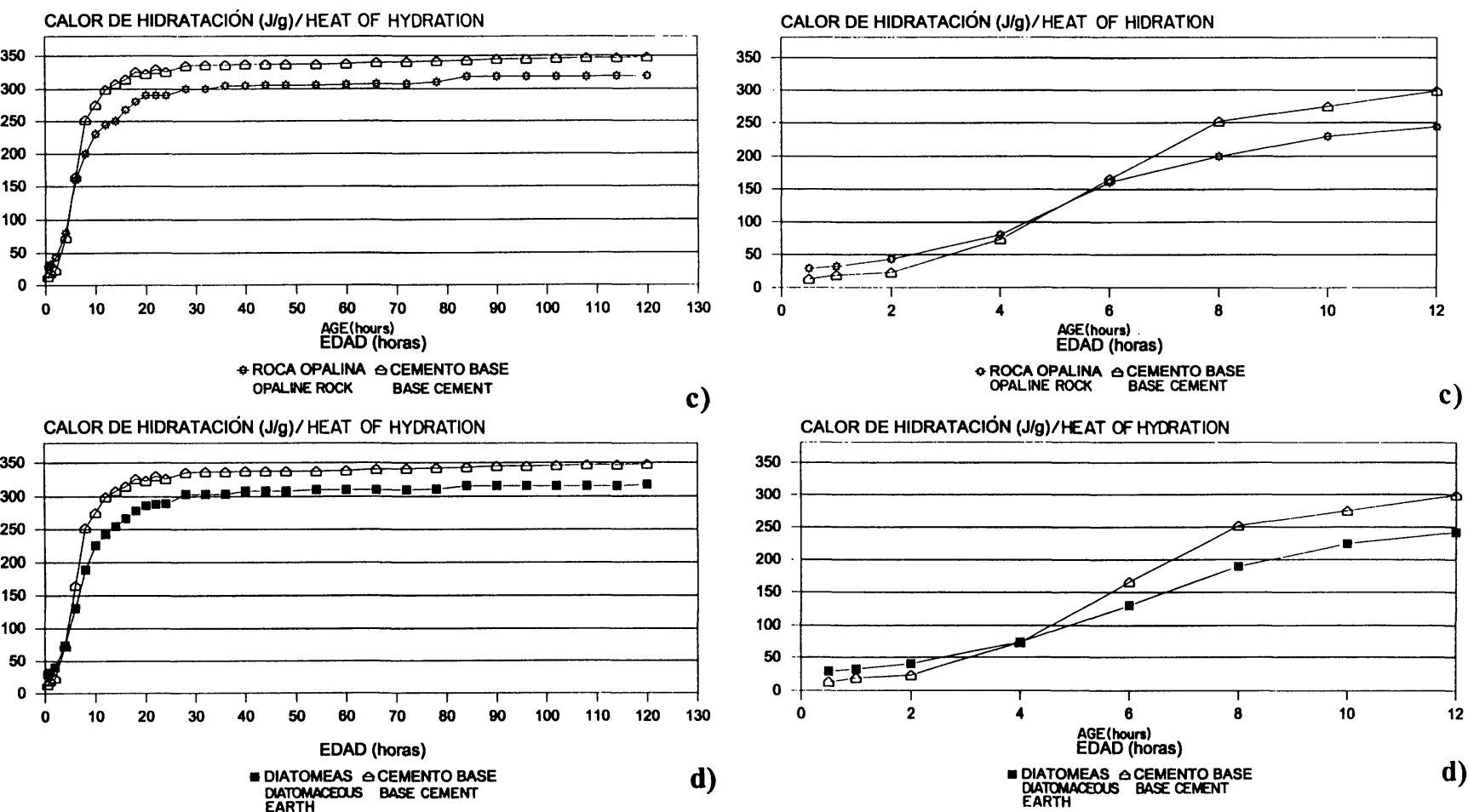

Figura 1.- Evolución del calor de hidratación: a) Puzolana natural, b) Toba volcánica, c) Roca opalina y d) Tierra de diatomeas

Figure 1.- Heat of hydration evolution: a) Natural pozzolan, b) Volcanic tuuf, c) Opaline rock and d) Diatomaceous earth.
In figures 1, 2, 3 and 4, the evolution of the heat of hydration with time is collected, until 5 days $(120$ hours) of mortars prepared with the different materials used, with a cement/admixture ratio of 70:30.

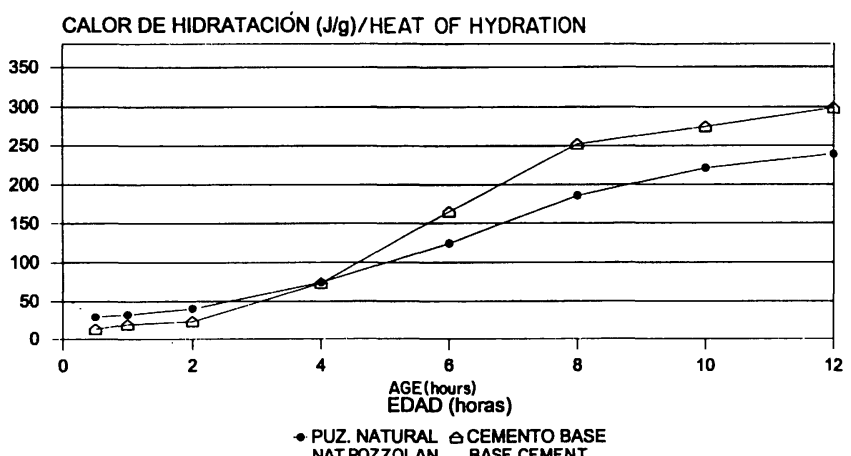

CALOR DE HIDRATACIÓN (J/g)/HEAT OF HYDRATION

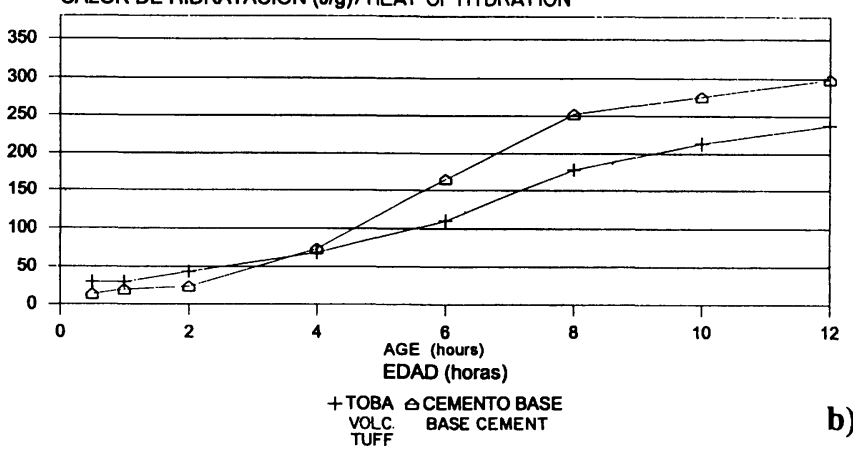

b) 

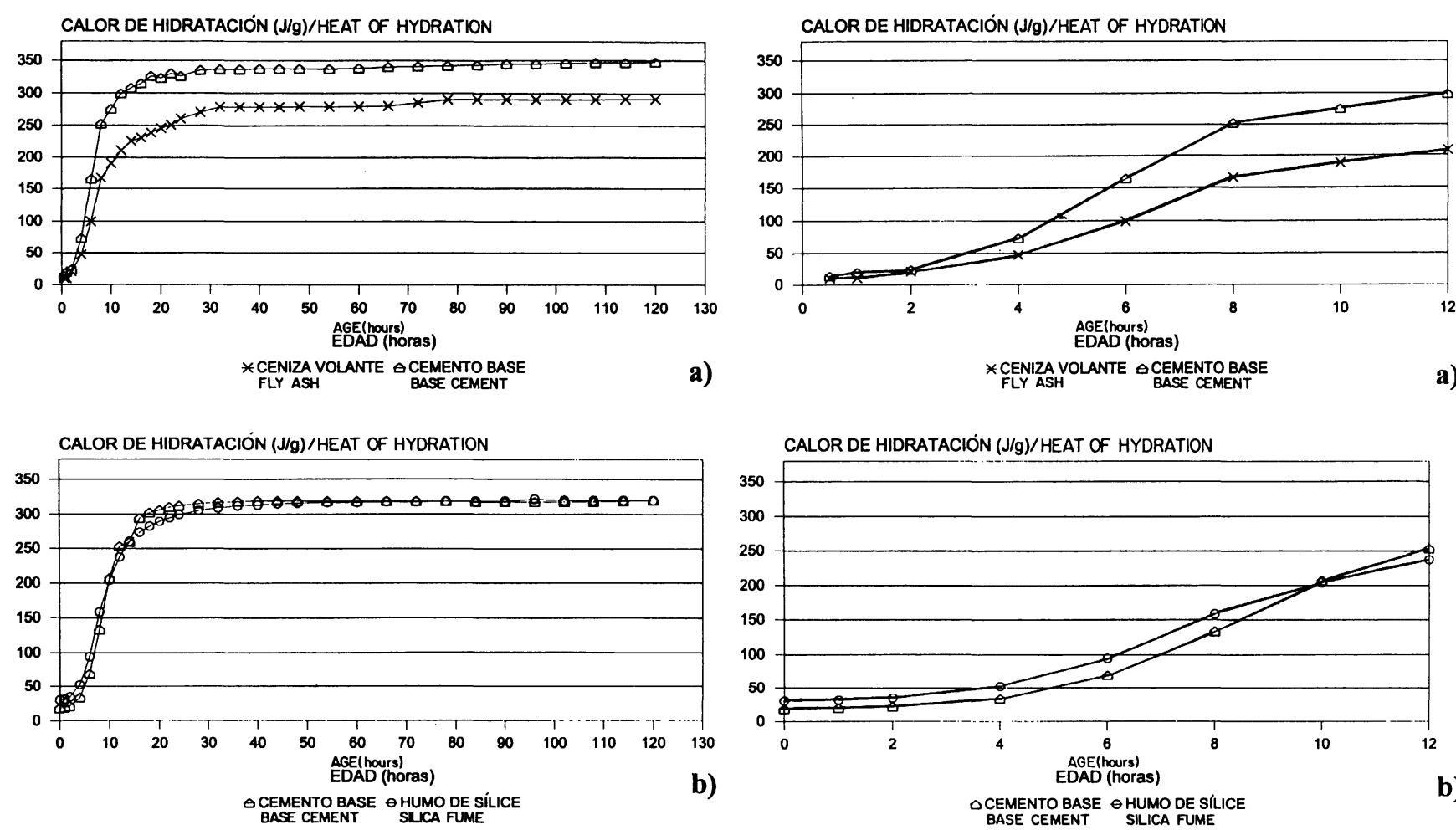

Figura 2.- Evolución del calor de hidratación: a) Ceniza volante, b) Humo de sílice.

Figure 2.- Heat of hydration evolution: a) Fly ash, b) Silica fume.

Al estar todos los materiales incorporados en el mismo porcentaje, se puede comprobar el efecto que cada uno de ellos produce sobre el calor de hidratación en relación al cemento portland base de referencia.

En las primeras horas del ensayo (hasta 12 horas), se observa cómo las adiciones, que presentan una actividad mayor a primeras edades, incrementan, en su mayoría, el calor de hidratación, en relación al filler calizo y la ceniza volante.

Sin embargo, a partir de las 5-6 horas y hasta las primeras 12 horas del ensayo, las reacciones son fuertemente exotérmicas y la pendiente ascendente de las curvas es elevada, apreciándose cómo el cemento base experimenta un mayor calor de hidratación en comparación con los cementos mixtos, a excepción de los morteros fabricados con materiales de alta actividad puzolánica.

Con el transcurso del tiempo, sigue jugando un papel importante la actividad del material. Así, la roca opalina, tierra de diatomeas, humo de sílice y metacaolin, adiciones que reaccionan rápidamente con la cal, dan lugar a su vez a reacciones exotérmicas, rebajando, en menor medida, el calor de hidratación, e incluso pueden producir morteros con un mayor desprendimiento de calor.
The effect of each of the materials on the heat of hydration may be verified because all are in the same proportion.

At the first hours of hydration (up to 12 hours), the additions present a high activity, increasing their heat of hydration with respect to the lime filler and the fly ash.

However, from 5 to 6 hours and until 12 hours of test, reactions are strongly exothermic and the increasing slope of the curves is high. The cement has higher heat of hydration compared to blended cements, except for the mortars manufactured with materials of high pozzolanic activity.

The activity material is still very important ast the time increases. Thus, the opaline rock, diatomaceous earth, silica fume and metakaolin, are additions react quickly with lime, giving place to exothermal reactions, decreasing the heat of hydration or even producing mortars with a higher heat released. 

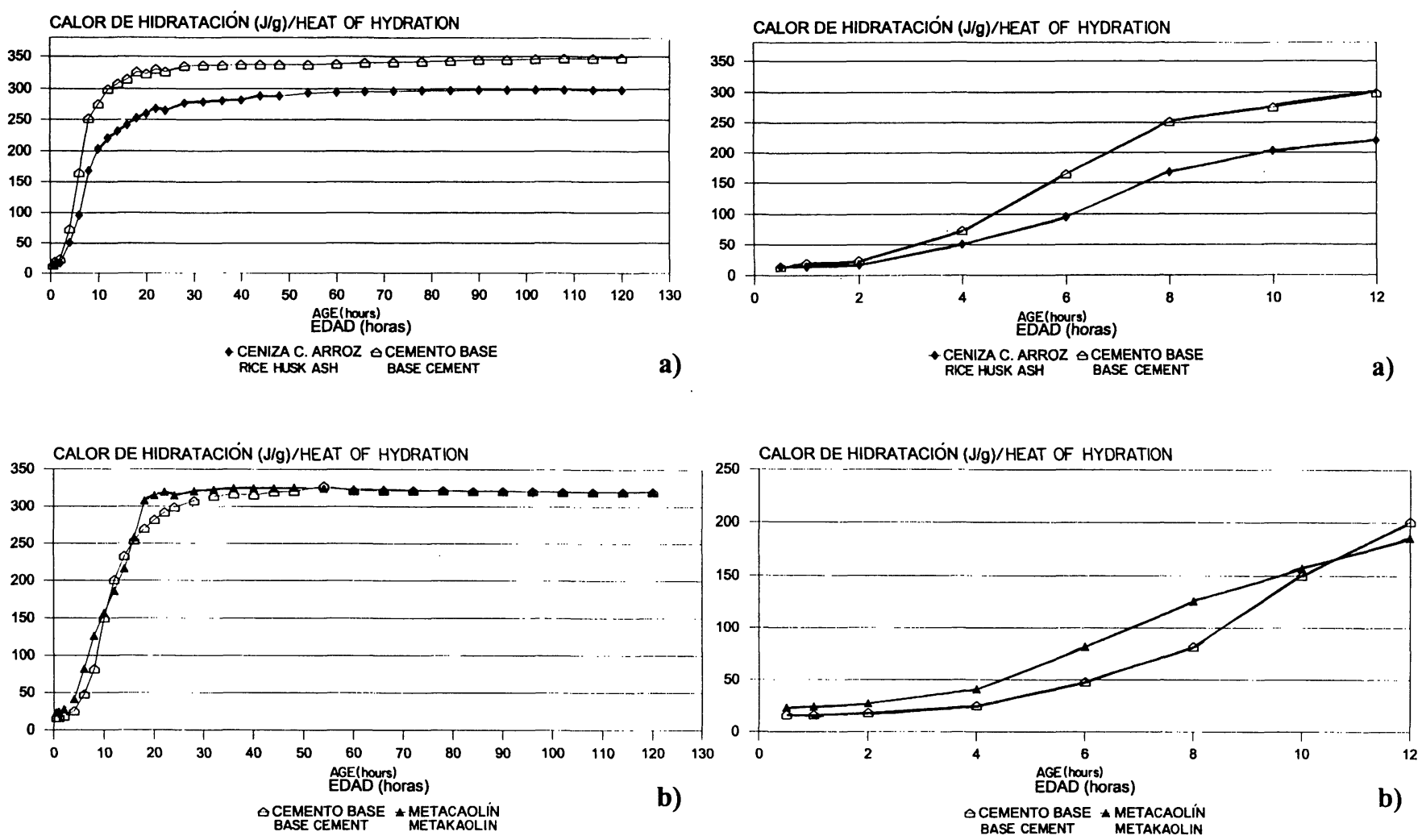

Figura 3.- Evolución del calor de hidratación: a) Ceniza cáscara de arroz, b) Metacaolín.

Figure 3.- Heat of hydration evolution: a) Rice husk ash, b) Metakaolin.

En la figura 5, se representa la disminución/incremento en el calor de hidratación de los morteros mixtos, referidas al mortero base, que aparece con valor cero, durante las primeras 14 horas de ensayo.

Los morteros que presentan comportamientos opuestos, son aquéllos elaborados con humo de sílice, metacaolin y ceniza volante. Los dos primeros incrementan el calor de hidratación en las primeras horas, mientras que la ceniza volante lo rebaja, en un porcentaje equivalente al de sustitución de cemento, durante todo el período de tiempo que dura la determinación.

Esto se debe a que el humo de sílice y el metacaolín presentan una alta reactividad a primeras edades y la ceniza volante manifiesta su capacidad puzolánica a más largo plazo, tal y como se observa en la figura 6, donde la actividad se representa como valor de cal fijada en el tiempo en $\mathrm{mM} / \mathrm{L}$.

En este hecho juega un papel importante la composición química del material puzolánico (contenido de componentes ácidos: $\mathrm{Si}, \mathrm{Al}, \mathrm{Fe}$ ), pero, sobretodo, el estado de cristalinidad de los minerales contituyentes. Así, el humo de sílice y el metacaolín presentan un bajo grado de cristalización, que da como resultado una alta reactividad frente a la cal, lo que no
In figure 5, the decrease/increase of the heat of hydration of blended mortars, referred to the reference mortar (with 0 value) during the first 14 hours of test is represented.

The mortars with opposite behaviour are those prepared with silica fume, metakolin and fly ash. The first two increase the heat of hydration in the first hours, whereas the fly ash decreases it in a percentage equivalent to the cement substitution all over the test time.

This is due to the high reactivity of the silica fume and metakaolin at first ages and the fly ash shows its pozzolanic activity at longer ages as it is observed in figure 6, where the activity is represented as the lime fixed with time in $\mathrm{mM} / L$.

The chemical composition of the pozzolanic material must be considered (content of acid components: Si, $\mathrm{Al}$ and $\mathrm{Fe}$ ), but mainly the crystallinity degree of these materials. So, silica fume and metakaolin have a low crystallinity degree, leading to a high 

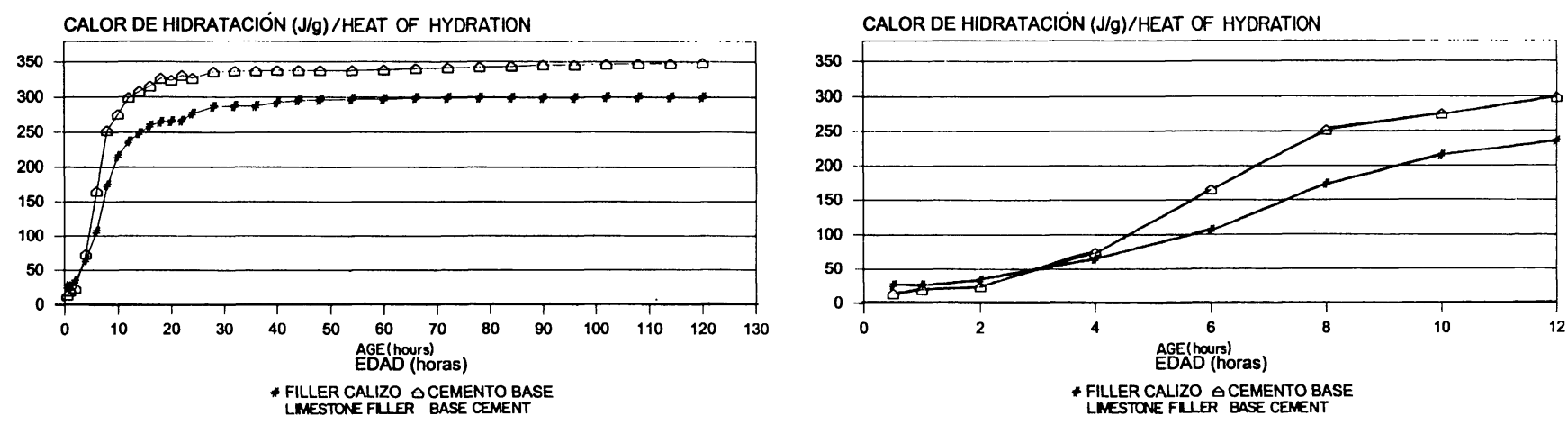

Figura 4.- Evolución del calor de hidratación. Filler calizo

Figure 4.- Heat of hydration evolution. Limestone filler.

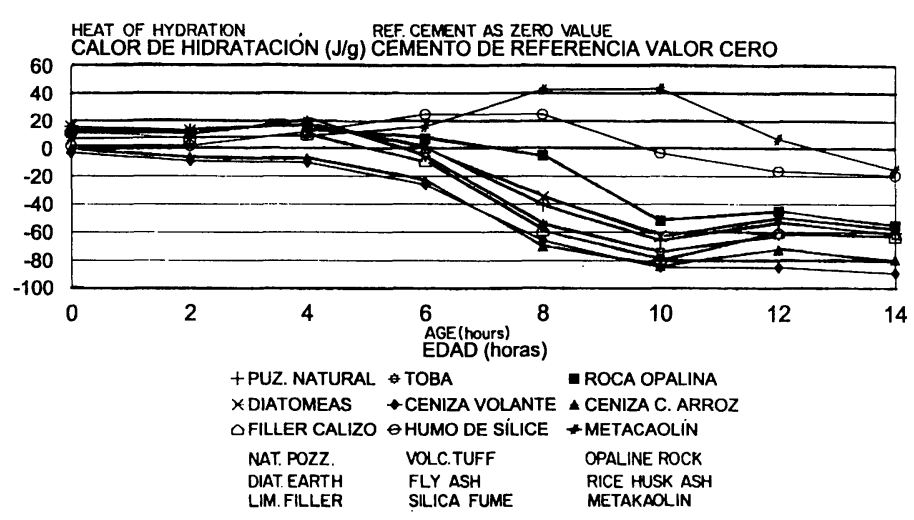

Figura 5.- Incremento/Disminución del calor de hidratación.

Figure 5.- Incremental/ Decrease of heat of hydration evolution.

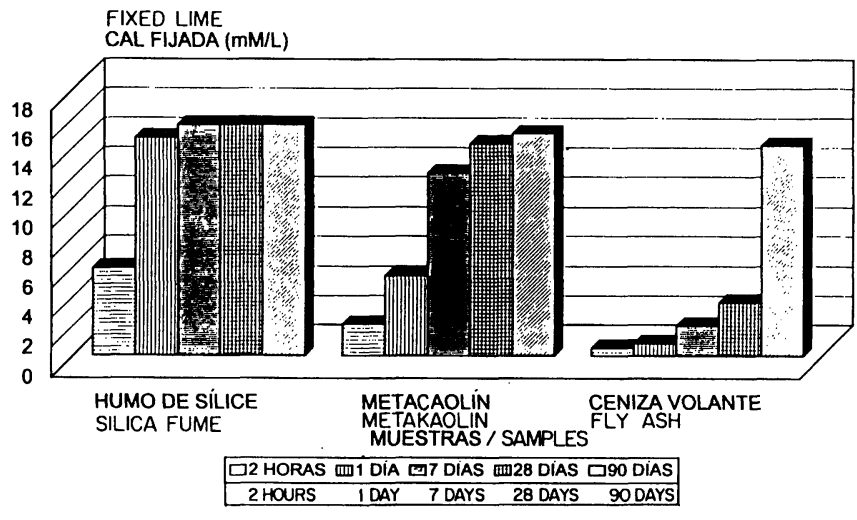

Figura 6.- Actividad puzolánica.

Figure 6.- Pozzolanic activity.

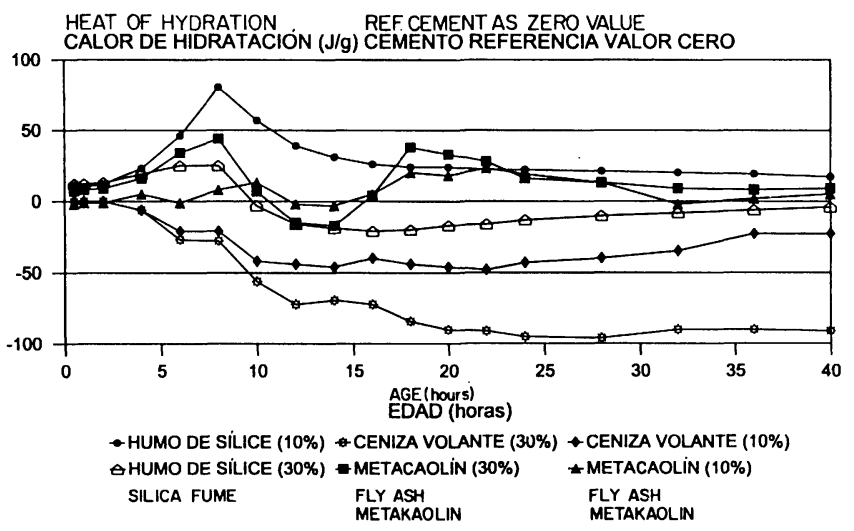

Figura 7.- Influencia del porcentaje de adición en el calor de hidratación.

Figure 7.- Addition percentage in the heat of hydration influence.

ocurre con la ceniza volante, cuyos componentes de estructuras más ordenadas o cristalinas precisan de mayor tiempo de reacción.

El nivel de sustitución de cemento, puede afectar a lo anteriormente expuesto. En el caso del humo de sílice, figura 7, se observa cómo el mortero que lleva incorporado humo de sílice en un porcentaje del 10\%, reactivity upon lime. This does not occurred with fly ash, whose components more ordered need longer reaction time.

The substitution of cement level may affect that described above. In the case of silica fume, figure 7, the mortar with silica fume in 10\%, has higher heat 
experimenta un mayor desprendimiento de calor que el cemento de referencia en todo el intervalo de medida. Sin embargo, a partir de las 10 horas, cuando la proporción de este subproducto es de $30 \%$, el calor de hidratación se sitúa por debajo del mortero base. Esto es debido a que el porcentaje de sustitución de cemento contrarresta el calor procedente de la reacción puzolánica, predominando el efecto de sustitución sobre el efecto de actividad puzolánica. Con el metacaolín ocurre un caso similar, aunque existen ciertas variaciones debidas a las reacciones específicas de este producto frente al hidróxido cálcico (12), donde las reacciones de formación de compuestos hidratados de aluminio juegan un papel importante en el desarrollo o evolución en el calor desprendido (13-14).

Sin embargo, en el caso de la ceniza volante la disminución de calor de hidratación se consigue en todos los morteros sea cual sea el porcentaje incorporado.

\section{4.- CONCLUSIONES}

De lo expuesto, se deduce que el empleo de puzolanas en los cementos, excepto aquéllos que tengan una alta actividad, reduce el calor desprendido durante la hidratación; sin embargo, también hay que tener en cuenta las reacciones del material puzolánico con la cal, que, a su vez, desprenden calor y hacen que la disminución no sea proporcional al grado de sustitución de clínker en el cemento mixto.

Por lo tanto, a la hora de seleccionar un material puzolánico, para la elaboración de cementos de bajo calor de hidratación, hay que considerar, primeramente, la actividad del producto, que vendrá determinada por la composición química y mineralógica del mismo, ya que no todos van a tener un mismo comportamiento térmico.

\section{AGRADECIMIENTOS}

Este estudio ha sido posible gracias a un Proyecto de Investigación (AMB96-1095) financiado por la Comisión Interministerial de Ciencia y Tecnología (CICYT).

\section{BIBLIOGRAFÍA}

(1) Soria, F.: "Estudio de Materiales: IV-Conglomerantes hidráulicos. Instituto Eduado Torroja de la Construcción y del Cemento. CSIC. Madrid.pp. 186(1980).

(2) Springenschmid, R.: "Cracks in Concrete Caused by the Heat of Hidration". Zement Kalk Gips, N. 3, 132-138 (1991).

(3) Roy, D.M.: "Fly ash and silica fume chemistry and hidration". Third Int. Conference Fly ash, silica fumer, slag, natural pozzolans in concrete. Trindheim, Norway, vol. 1, 117-138(1989).

(4) Massazza, F.: "Structure of pozzolan and fly ash and the hidration of pozzolanic and fly ash cments. 7 th Int. Congress on the chemistry of cements. Paris. IV. 85-96 (1980). release that the reference mortar. However, from 10 hours of test, when the by-product amount is 30\%, the heat of hydration is lower than that of the reference mortar. This is because the substitution percentage balances the heat from the pozzolanic reaction, prevailing the substitution effect. The case of metakaolin is similar, although some variations exist due to specific reactions of this product with calcium hydroxide (12), where reactions of aluminium hydrates are very important in the development or evolution of the heat released (13-14).

However, in the case of fly ash, the decrease of the heat of hydration appears in all mortars regardless the percentage incorporated.

\section{4.- CONCLUSIONS}

The utilisation of pozzolans in cements, except those with high activity, decreases the heat of hydration; however, this decrease is not proportional to the clinker substitution in the blended cement because of the heat released in the reaction of the material with lime.

Thus, to select the pozzolanic material for the elaboration of low heat of hydration cement, it must be firstly considered the product activity, determined by the chemical, mineralogical composition of the product that will determine its thermal behaviour.

\section{ACKNOWLEDGMENTS}

The authors wish to thank the CICYT for funding this research through the AMB96-1095 project. 
(5) Sánchez de Rojas, M. I.; Luxán, M. P.;Frías, M.; N. García: "The influence of different additions on portland cement hydration heat". Cement and Concrete Research, V. 23, N.1 , 46-54 (1993).

(6) Sánchez de Rojas, M. I.; Frías, M.: “The influence of silica fume on the heat of hydration of portland cement". Fifth CANMET/ACI Int. Conference Fly Ash, Silica Fume, Slag and Natural Pozzolans in Concrete. Vol. 2, 829-843. Milwaukee, Wisconsin, USA (1995).

(7) Salas, J.; Castillo, P.; Sánchez de Rojas, M. I.; Veras, J.: “Use of Rice Husk Ash an Addition in Mortar”. Materiales de Construcción, 36,21-39(1986).

(8) Norma UNE 80 301: "Cementos. Definiciones, Clasificación y Especificaciones".

(9) Frías, M.; Sánchez de Rojas, M. I.; Luxán, M. P.; García, N.: "Determination of specific surface area by the laser diffraction techique, comparison with the blaine permeability method". Cement an Concrete Reseach, 21, N. 5, 709-717 (1991).

(10) Norma UNE 80118 : "Métodos de Ensayo de Cementos. Ensayos Físicos: Determinación del Calor de Hidratación por Calorimetría Semi-adiabática (Método del Calorímetro de Langavant)".

(11) Alegre, R.: "La Calorimétrie des Ciments au CERILH". Revue des Matériaux, (547), 218-229. (548), 247-262 (1961).

(12) Frías, M.; Sánchez de Rojas, M.I.; Cabrera, J.: "The effect that the pozzolanic reaction of metakaolin has on the heat evolution in metakaolin-cement mortars". Cement and Concrete Research , 30 (2000), 209-216..

(13) Cabrera, J.; Frías, F.: "Mechanism of the MK/lime/water system". Cement and Concrete Research (en prensa, 2000).

(14) Frías, M.; Cabrera, J.: "The effect of temperature on the hydration rate and stability of the hydration phases of MK/lime/water systems". Cement and Concrete Research (en revisión, 2000).

\section{publicaciones del IETCC/CSIC}

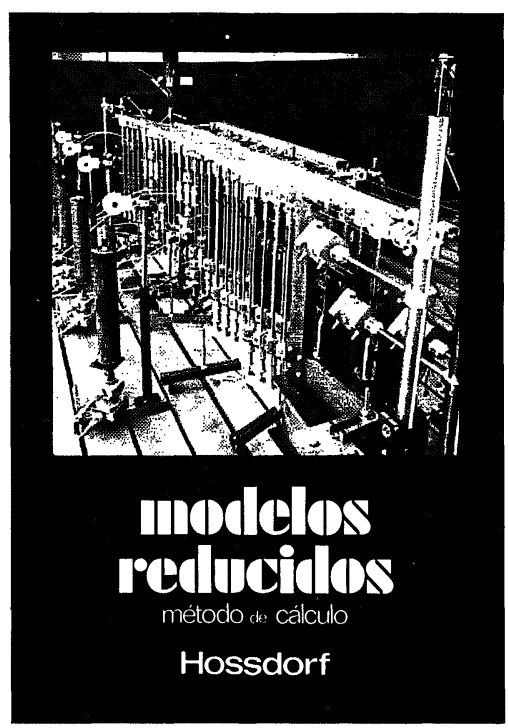

Modelos reducidos. Método de cálculo

H. Hossdorf, Ingeniero Civil

La técnica de los ensayos en modelos reducidos de estructuras sufre hoy dia una decisiva metamorfosis.
Hasta hace poco era un medio más bien de artesania, que no siempre era tomado en serio por los académicos teorizantes para comprender el comportamiento resistente de las estructuras complejas y a que se acudió las más de las veces, como a un último remedio debido a sus indiscutibles insuficien cias. Sin embargo, en poco tiempo y gracias a su conexión con los ordenadores digitales, se ha transformado en un instrumento cientificamente valioso que no puede quedar a un lado en la práctica diaria del Ingeniero Proyectista.

Un volumen encuadernado en cartoné plastificado con lomo de tela, de $17 \times 24 \mathrm{~cm}$, compuesto de 250 páginas, 158 figuras $y$ fotografias.

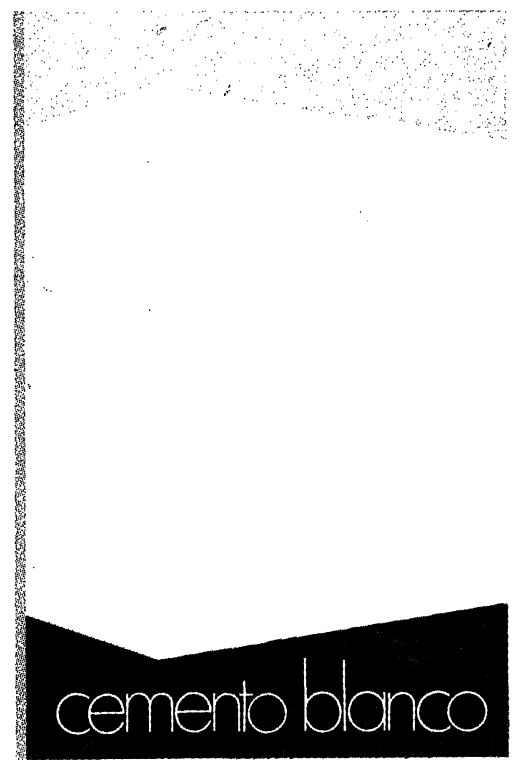

Cemento blanco

Juliàn Rezola

Ingeniero Quimico Dipl. I. Q. S

Sabido es que existe una extensa y documentada bibliografia sobre el cemento gris: en cambio, no puede decirse lo mismo acerca del cemento portland blanco, va que los escritos existentes se refieren tan de aquél.

El autor nos ofrece sus profundos conocimientos $y$ su larga experiencia tanto en laboratorio como en fabricación.

La parte descriptiva del libro se complementa con gráficos, diagramas $y$ fotografias de gran utilidad, destinados a conseguir la aplicación apropiad

Un volumen encuadernado en cartoné policerado, de $17,4 \times 24,3 \mathrm{~cm}$, compuesto de 395 páginas, numerosas figuras, tablas y ábacos.

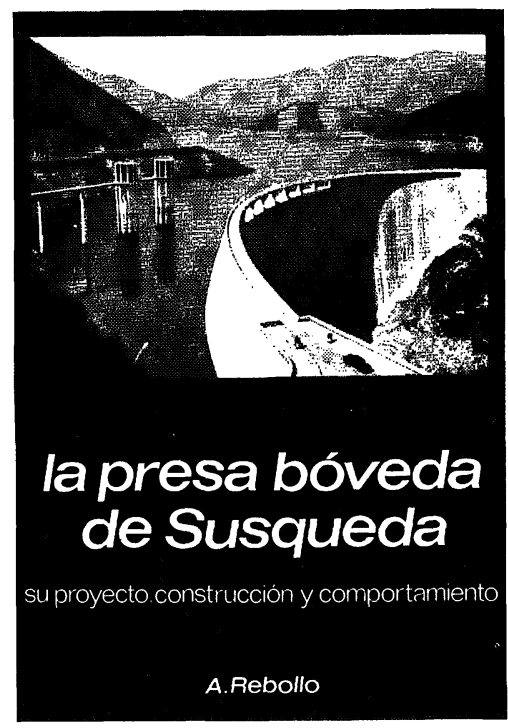

La presa bóveda de Susqueda

A. Rebollo,

Dr. Ingeniero de Caminos

El esfuerzo del constructor de presas se sitúa por su pretensión de perennidad, a contracorriente de las tendencias de la civilización actual, caractegrand por lo tungible. Pueden evocarse las 10.000 grandes presas en flncionamiento o en constucción que están envejeciendo $y$ veclom $y$ en constuccion gerontológicos para mantener $y$ perfeccionar su

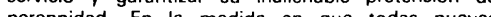
peras, grandes riesgos ecologicos $y$ a veces, catastróficos, aumentan con el envejecimiento la las presas es todo un emplazo. La accion adelantada la Arturo Rebollo en este terreno marca un camino a seguir para todos los que aman su propia camino la devoción paternal que el ha puesto en Susqueda.

Un volumen encuadernado en cartoné plastificado con lomo de tela, de 18 、 $24,5 \mathrm{~cm}$, compuesto de 408 páginas, 330 figuras $y$ fotografias $y 39$ tablas. 